\title{
Pattern of acne vulgaris in women, attending in a tertiary care hospital.
}

\author{
Khondker L $L^{1}$, Rahman $M^{2} M^{2}$ Mahmud $M^{3}$, Khan MSI ${ }^{4}$ Khan $H^{5}$, Kabir $H^{6}$ \\ ${ }^{1}$ Assistant professor, Department of Dermatology and Venereology, Bangabandhu Sheikh Mujib Medical University, Dhaka, \\ ${ }^{2}$ Assistant professor, Department of Skin and Venereal diseases, Dhaka National Medical College Hospital, Dhaka, ${ }^{3}$ Registrar, \\ Department of Skin and Venereal diseases, Shaheed Sohrawardy Medical College Hospital, Dhaka, ${ }^{4}$ Specialist in Dermatology, \\ Combined Military Hospital, Dhaka, ${ }^{5}$ Assistant professor, Department of Skin and Venereal diseases, Dhaka Medical College \\ Hospital, Dhaka, ${ }^{6}$ Assistant professor, Department of Cardiology, National Institute of Cardio-vuscular Diseases \& Hospital, Dhaka.
}

\begin{abstract}
A cross-sectional study was carried out for a period of one year in the outpatient department of Dermatology and Venereology, Bangabandhu Sheikh Mujib Medical University (BSMMU), Dhaka, Bangladesh. Seventy female patients having acne vulgaris were selected. The study showed that the mean age of the cases was 22.43 with standard deviation 5.2 years and highest percentage of patients were in the age group 20-24 years (41.4\%), highest percentage of patients was unmarried among the cases $(74.3 \%)$ and proportion of secondary $(35.7 \%)$ and higher secondary education (20\%) were found to be high among the cases. The study showed that proportion of student $(65.7 \%)$ and housewife $(\mathbf{1 7 . 1 \%})$ were found to be high among the cases. The mean duration of disease was 62.6 months and all the patients had presented with comedones (blackheads and whiteheads). All the patients had acne in the face and it was found that $60 \%$ had moderate type acne. Considering the pattern of treatment received, $\mathbf{4 2 . 9 \%}$ of the patients mentioned that they used topical ointment, $37.1 \%$ had received herbal medication and $25.7 \%$ had received systemic medication. To get an overall impression of the country regarding acne vulgaris, more integrated study is needed. This was a study on a limited number of cases. Future studies must include economical support, then large sample size could be ensured and study finding would be more reliable. There is a great need of epidemiological studies also, with sufficient follow-up, systematic reviews and meta-analyses on this issue.
\end{abstract}

Key words: Acne vulgaris, pattern of acne.

\section{Introduction:}

Acne vulgaris is the most common disease involving the pilosebaceous unit, affecting in particular the face, back and chest although occasionally it may be wide spread. ${ }^{1}$ It is a chronic inflammatory disease of the pilosebaceous follicles characterized by comedones, papules, pustules, cysts, nodules and often scars. ${ }^{2}$ The condition usually starts in adolescence and resolves by the mid-twenties. However, in 7-17\% of individuals clinical acne persists beyond the age of 25 years with physiological acne in females having a prevalence of $24 \%$. A genetic influence is confirmed by the very high concordance between monogygotic twins, in whom the sebum excretion rate (SER) is virtually identical. Patients with persistent acne have a strong family history of persistent acne, in contrast to patients with adolescent acne. ${ }^{3}$

Active sebaceous glands are a prerequisite for the development of acne. Acne patients, male and female, excrete on average, more sebum than normal subjects and the level of secretion correlates reasonably well with the severity of the acne. One of the components of sebum, triglycerides may play a role in acne pathogenesis. Triglycerides are broken down into free fatty acids by P. acnes, normal flora of pilosebaceous unit. These free fatty acids (FFA) promote further bacterial clumping and colonization of $\mathrm{P}$. acnes, incite inflammation and may be comedogenic. ${ }^{4}$ Sebaceous activity is predominantly dependent on androgenic hormones of gonadal or adrenal origin. An important feature in the aetiology of acne is the presence of ductal hypercornification. ${ }^{3}$ Several proposed factors in keratinocyte hyperproliferation include: androgen stimulation, decreased linoleic acid and increased IL$1 \alpha$ activity. ${ }^{4}$

The three major organisms isolated from the surface of the skin and pilosebaceous ducts of patients with acne are P. acnes, Staphylococcus epidermidis and Malassezia furfur. ${ }^{3} \mathrm{P}$. acnes plays an active role in the process of inflammation. ${ }^{4} \mathrm{P}$. acnes is non motile but easily colonizes the duct. In early inflammation proinflammatory mediators move through the duct wall into the dermis. In papules, helper $\mathrm{T}$ cells are the first inflammatory cells to be seen. ${ }^{3}$ As the retained cells block the follicular opening, the lower portion of the follicle is dilated. ${ }^{2}$ Eventually this distension causes follicular wall rupture. ${ }^{4}$ The combination of keratin, sebum and microorganisms particularly P. acnes leads to release of proinflammatory mediators. ${ }^{2}$

The predominant cell type within 24 hours of comedo rupture is the lymphocyte. CD4+ lymphocytes are 
J. Dhaka National Med. Coll. Hos. 2012; 18 (01): 18-23 found around the pilosebaceous unit whereas CD8+ cells are found perivascularly. One to two days after comedo rupture, the neurophil becomes the predominant cell type surrounding the burst microcomedo. ${ }^{4}$

Nodules more frequently occur in males and if exudative or haemorrhagic, are particularly disfiguring and messy. Scarring usually follows deep inflammatory lesions but may often happen after superficial lesions in scar-prone patients. Scars may show increased collagen (hypertrophic scars and keloids) or be associated with loss of collagen (i.e. ice pick scars, depressed fibrotic scars, atrophic macules and peri-follicular elastolysis). ${ }^{3}$ Diagnosis is usually easy but acne may be confused with folliculitis, rosacea or perioral dermatitis. These do not have comedone. Acne can also be seen in association with different endocrinologic abnormalities, such as polycystic ovarian syndrome including hyperandrogenism, insulin resistance, canthosis nigricans, hirsutism, deepening of voice, irregular menses etc.Various acne treatments targets different elements in acne pathogenesis. ${ }^{4}$

The management of acne starts with education. This is largely determined by the severity and extent of the disease but should be tempered by patient choice and cost. Patient with mild acne usually receive topical therapy alone; patients with moderate acne receive oral and topical therapies; patients with severe acne should immediately receive oral isotretinoin unless contraindicated. $^{3}$

\section{Materials and Methods:}

It was a cross-sectional study. The study was carried out for a period of one year from March 2010 to February 2011, in the outpatient department of Dermatology and Venereology, Bangabandhu Sheikh Mujib Medical University (BSMMU), Dhaka, Bangladesh. Female patients having acne vulgaris were selected as study population. Purposive type of non-probability sampling technique was followed. Data were recorded on pre designed data collection sheet. Within the period of data collection, patients were assigned purposively considering exclusion and inclusion criteria of patient selection.

\section{Inclusion criteria for case:}

Patients having clinically diagnosed acne vulgaris. (Seborrhea i.e. greasy skin, comedones, papules, pustules, nodules and scarring, in some cases, predominantly on the face and to a lesser extent on the back and chest.) i. Female patients of age 13 to 45 years.

ii. Patients willing to participate in this study.

\section{Exclusion criteria for case:}

i. Pregnant women and lactating
mothers.
ii. Patients treated with oral
contraceptive pill, antiandrogen,
systemic antibiotics and oral
retinoids within 3 months prior to
the study.

\section{Study procedure:}

Clinically suspected cases of acne vulgaris attending in the outpatient Department of Dermatology and Venereology, BSMMU, Dhaka were seen. All women participating in the study gave informed consent. According to a structured questionnaire their particulars and history were taken. Patients for the study were selected on the basis of history, clinical examination and inclusion and exclusion criterias. Acne vulgaris was diagnosed by seborrhea (greasy skin), comedones, papules, pustules, nodules and scarring, in some cases, predominantly on the face and to a lesser extent on the back and chest.

Acne was graded according to the Consensus Conference on Acne Classification convened by American Academy of Dermatology in Washington DC on march 24 and 25, 1990. ${ }^{5}$ According to these criteria, mild acne is defined by the presence of comedones, without significant inflammation and a few or no papules; moderate acne, by the presence of comedones, with marked inflammatory papules and pustules and severe acne, by the presence of inflammatory nodules, in addition to comedones, papules and pustules.

\section{Ethical consideration:}

Prior to the commencement of this study, the research protocol was approved by the ethical review committee of BSMMU. The aims and objectives of the study along with its procedure, risk and benefits were explained to the patients in easily understandable local language and then informed consent was taken from each patient. It was assured that all information and records were kept confidential and the study would be helpful for both the dermatologists and the patients in making rational approach of the case management. 
J. Dhaka National Med. Coll. Hos. 2012; 18 (01): 18-23 Data processing and analysis:

Relevant data was collected in a preformed data collection sheet for each patient from the history, clinical examination and biochemical report. After collection, data was checked for inadequacy, irrelevancy and inconsistency. Irrelevant data was discarded. For the statistical analysis, one Microsoft windows-based software package was used (SPSS [Statistical Package for Social Science] 15 for Windows, SPPS Incorporation, Chicago, IL, USA).

\section{Results:}

The study was carried out for a period of one year from in the outpatient department of Dermatology and Venereology, Bangabandhu Sheikh Mujib Medical University (BSMMU), Dhaka, Bangladesh. Female patients having acne vulgaris were selected as study population. Table- I showed that the mean age of the cases was 22.43 with standard deviation 5.2 years and data showed that the highest percentage of patients were in the age group 20-24 years (41.4\%) followed by less than 20 years (31.4\%), 25-29 years $(15.7 \%)$ and lowest in the age group 35 years and above (4.3\%). It was showed that highest percentage of patients was unmarried among the cases (74.3\%). Table- I showed that proportion of secondary $(35.7 \%)$ and higher secondary education (20\%) were found to be high among the cases and the proportion of student (65.7\%) and housewife (17.1\%) were found to be high among the cases.

The mean duration of disease was 62.6 months ranging from 12 months to 300 months. It was found that $28.6 \%$ of the respondents had duration 12 to 24 months and equal percentage had 25-48 months. However, $27.1 \%$ of the patients mentioned that they were suffering from more than 6 years. All the patients had presented with comedones (blackheads and whiteheads) followed by $94.3 \%$ had papules and $58.6 \%$ had pustules. Considering the site of lesion, all the patients had acne in the face. However, $17.1 \%$ of the patients had acne in the back along with face. It was found that two fifths (40\%) of the patients presented with mild acne and the $60 \%$ had moderate acne (Table II).

Considering the pattern of treatment received, $42.9 \%$ of the patients mentioned that they used topical ointment, $37.1 \%$ had received herbal medication and $25.7 \%$ had received systemic medication (Figure 1).

Table- I: Distribution of the patients by age, marital status, level of education and occupation.

\begin{tabular}{lll}
\hline Age in years & No. & $\%$
\end{tabular}

\begin{tabular}{|c|c|c|c|}
\hline$<20$ & 22 & 31.4 & \\
\hline $20-24$ & 29 & 41.4 & \\
\hline $25-29$ & 11 & 15.7 & \\
\hline $30-34$ & 5 & 7.1 & \\
\hline$\geq 35$ & 3 & 4.3 & \\
\hline Mean $\pm S D$ (years) & $22.43 \pm 5.2$ & & \\
\hline Marital status & No. & $\%$ & \\
\hline Unmarried & 52 & 74.3 & \\
\hline Married & 18 & 25.7 & \\
\hline Level of education & No. & $\%$ & \\
\hline Primary & 4 & 5.7 & \\
\hline Secondary & 25 & 35.7 & \\
\hline Higher Secondary & 14 & 20.0 & \\
\hline Graduate or higher & 27 & 38.6 & \\
\hline Occupation & No. & & $\%$ \\
\hline Student & 46 & & 65.7 \\
\hline Service holder & 12 & & 17.1 \\
\hline Housewife & 12 & & 17.1 \\
\hline
\end{tabular}

Table II: Distribution of the patients by duration of

disease, pattern of skin lesion, and its site.

\begin{tabular}{|c|c|c|}
\hline $\begin{array}{l}\text { Duration } \\
\text { disease(months) } \\
12-24\end{array}$ & $\begin{array}{l}\text { Number } \\
20\end{array}$ & $\begin{array}{c}\text { Percentage } \\
28.6\end{array}$ \\
\hline $25-48$ & 20 & 8.6 \\
\hline $49-72$ & 11 & 15.7 \\
\hline$\geq 73$ & 19 & 27.1 \\
\hline $\begin{array}{l}\text { Mean (SE) } \\
\text { Range }\end{array}$ & $\begin{array}{l}62.57(6.4) \\
12,300\end{array}$ & \\
\hline \multicolumn{3}{|l|}{ *Pattern of skin lesion } \\
\hline Comedones & 70 & 100.0 \\
\hline Papules & 66 & 94.3 \\
\hline Pustules & 41 & 58.6 \\
\hline \multicolumn{3}{|l|}{ *Site of lesion } \\
\hline Face & 70 & 100.0 \\
\hline Back & 12 & 17.1 \\
\hline \multicolumn{3}{|l|}{ Severity of acne } \\
\hline Mild & 28 & 40.0 \\
\hline Moderate & 42 & 60.0 \\
\hline
\end{tabular}

*Multiple responses 
Figure 1: Distribution of the patients by pattern of treatment received $(n=70)$.
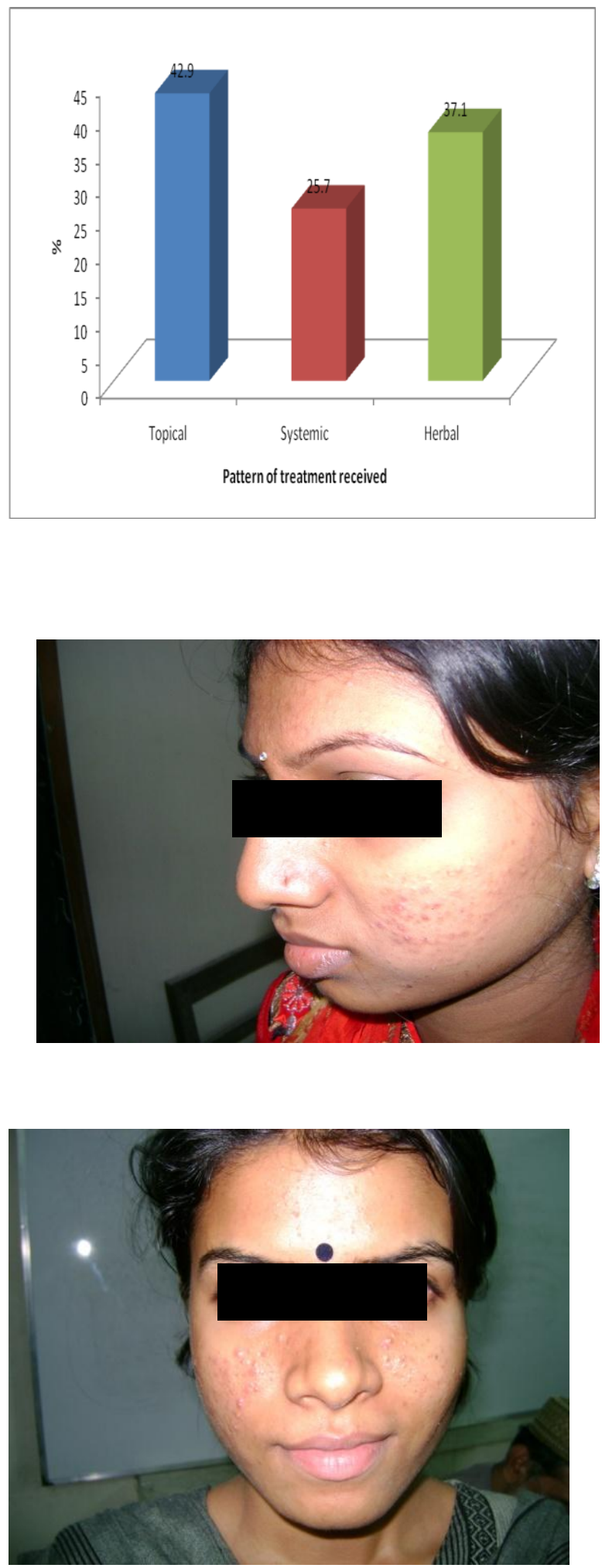
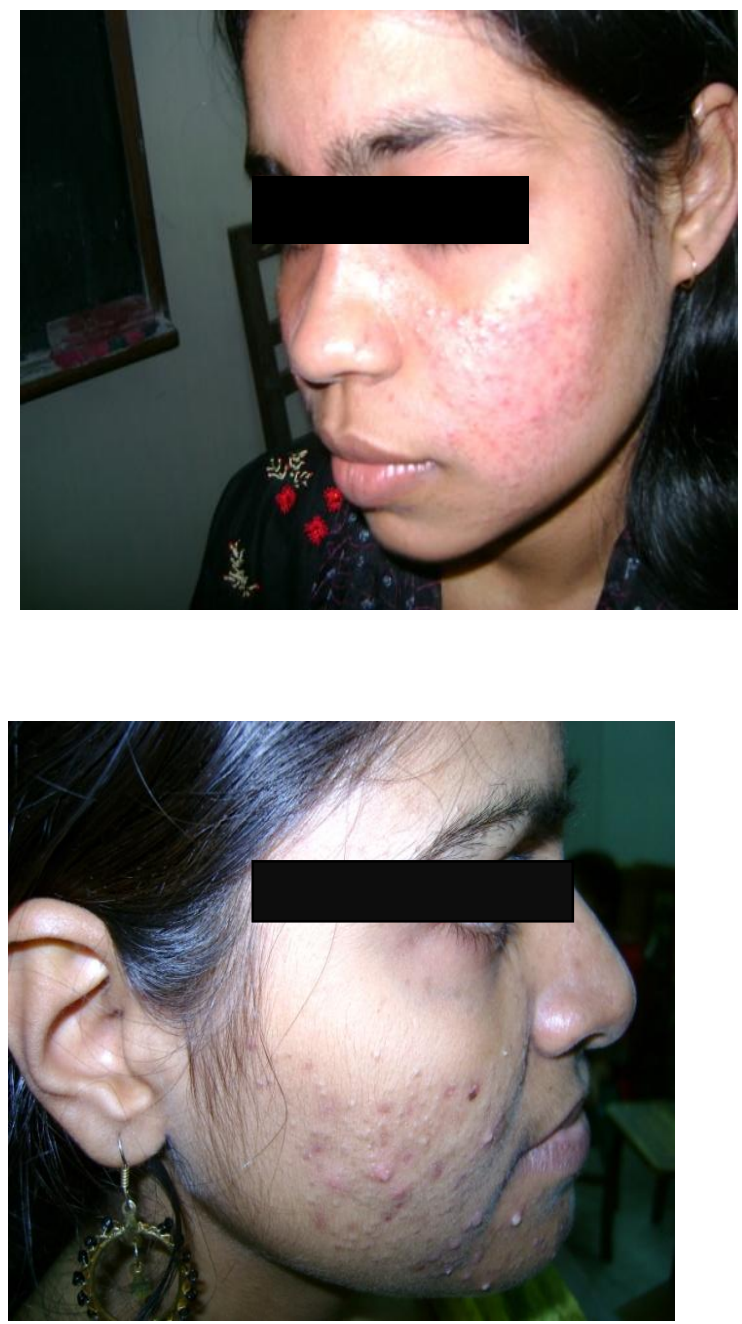

Figure II: Photograph showing female with acne vulgaris in their face.

\section{Discussion:}

This study was carried out in the Department of Dermatology and Venereology, Bangabandhu Sheikh Mujib Medical University, Dhaka. Age of the patients in this study ranged from 13 to 40 years. The mean age of the cases was 22.43 years with standard deviation 5.2 years. In a case control study by Slayden et al. ages of the women ranged from 12 to 43 years. Patients with acne and controls had similar mean $( \pm \mathrm{SD})$ age $(26.5 \pm 9.3$ years vs. $29.2 \pm 4.7$ years respectively). ${ }^{5}$

The mean duration of the disease in our study was 62.6 months (5.2 years) ranging from 12-300 months (1-25 years). It was found that $28.6 \%$ of the patients had duration 12-24 months and equal percentage had 25-48 months of illness and $27.1 \%$ of the patients were suffering from acne for more than 72 months. 
J. Dhaka National Med. Coll. Hos. 2012; 18 (01): 18-23 Zaenglein et al. found that in women acne persisted through the third decade or even later, which was consistent with this study. ${ }^{4}$ In contrast to our study, Hatwal et al. 1990 found that the mean duration of acne was 2.6 years (range 1 to 6 years). ${ }^{6}$ Borgia et al. 2004 reported mean duration of disease $5.9 \pm 4.6$ years. $^{7}$

All of our study patients presented with acne in the face. The lesions of acne vulgaris were present in the back along with face in $17.1 \%$ of the cases. Simpson and Cunliffe 2004 showed that acne occurred predominantly on the face (99\% of sufferers) and to a lesser extent, occurred on the back $(60 \%)$ and chest $(15 \%) .{ }^{3}$ Considering the affection of face our study was consistent with that of Simpson and Cunliffe.

In our study, $40 \%$ of patients had mild acne and $60 \%$ had moderate acne. In their case control study, Lookingbill et al. showed that mild acne was present in $44.44 \%$ of cases and moderate acne in $55.55 \%$ of cases. $^{8}$ These two findings were almost consistent with each other.

Cibula et al. evaluated and examined the women consecutively in an outpatient unit for acne vlugaris over the years 1998-99 were included in the study. Inclusion criteria were age over 17 years, absence of hormonal therapy during the past 6 months and absence of therapy with systemic antibiotics or isotretinion at the time of examination. Patients with severe acne were not included as most women with this severity of acne did not meet the inclusion criteria of absence of systemic therapy. Ninety women over 17 years of age with acne were enrolled into the study. The patients were divided into three groups according to acne severity. Acne was graded using the Leeds technique as minor in $43(48 \%)$ cases, mild in $27(30 \%)$ and moderate in $20(22 \%) .{ }^{9}$

\section{Conclusion:}

This was a study on a limited number of cases. Future studies must include economical support, then large sample size could be ensured and study finding would be more reliable. There is a great need of epidemiological studies also, with sufficient follow-up, systematic reviews and meta-analysis on this issue.

\section{References:}

1. Cunliffe WJ. 'Acne Vulgaris: pathogenesis and treatment'. Br Med J 1980 June 14; 280(6229): pp1394-1396.
2. James WD, Berger TG and Elston DM . Acne vulgaris'. Andrews' Diseases of the skin. Clinical dermatology. $10^{\text {th }}$ ed. Philadelphia, USA: Saunders Elsevier publisher; pp. 231-239.

3. Simpson NB and Cunliffe WJ. 'Disorders of the sebaccous glands'. Rook's Text book of dermatology. $7^{\text {th }}$ ed, Massachusetts, USA: Black Well Science publisher; 2004pp. 43.1-43.58.

4. Zaenglein AL, Garber EM, Thiboutot DM and Strauss JS. 'Acne vulgaris and Acneiform Eruptions'. Fitzpatrick's Dermatology in General Medicine. $7^{\text {th }} \mathrm{ed}$, Sanfransisco, USA:, McGraw-Hill publisher; 2008.pp. 690-696.

5. Slayden SM, Moran C, Sams JWM, Boots LR and Aziz R. 'Hyperandrogenemia in patients presenting with acne'. Fertility and Sterility2001; vol. 75(5): pp. 889-892.

6. Hatwal A, Singh SK, Agarwal UK, Singh G, Bajpai HS and Gupta SS. 'Serum testosterone, DHEA-S and androstenedione levels in acne'. Indian Journal of Dermatology, Venereology and Leprology 1990; vol. 56: pp. 427-429.

7. Borgia F, Cannavo S, Guarneri F, Cannavo SP, Vaccaro $\mathrm{M}$ and Guarneri B. 'Correlation between Endocrinological Parameters and Acne severity in adult women'. Acta Derm Venereol2004; vol. 84: pp. 201-204.

8. Lookingbill DP, Horton R, Demers LM, Egan N, Marks Jr JG and Santen RJ. 'Tissue production of androgen in women with acne'. Journal of American Academy of Dermatology, vol. 1985; 12: pp. 481-487.

9. Cibula D, Hill M, Vohradnikova O, Kuzel D, Fanta $\mathrm{M}$ and Zivny J. 'The role of androgens in determining acne severity in adult women. British Journal of Dermatology2000; vol. 143: pp. 399-404.

10. Voegeli SK, Rey F, Reymond MJ, Meuwly JY, Gaillard RC and Gomez F. 'Androgen Dependence of Hirsutism, Acne and Alopecia in Women. Medicine2009; vol. 88: pp. 32-45.

11. Levell MJ, Cawood ML, Burke B, Cunliffe WJ. "Acne is not associated with abnormal plasma androgens'. British Journal of Dermatology1989; vol. 120: pp. 649-654. 
J. Dhaka National Med. Coll. Hos. 2012; 18 (01): 18-23 12. Kushlinskii NE, Salamova IV, Masyukova SA, Muhammad AKh, Degtyar VG and Samsonov VA. 'Sex Hormone Binding Globulin, Serum Testosterone and Androgen Receptors in the Skin in Papulopustular and Conglobata Forms of Acne Vulgaris'. Bulletin of Experimental Biology and Medicine1997; vol. 123(2): pp. 163-165.

13. Held BL, Nader S, Rigau LJR, Smith KD and Steinberger E. 'Acne and hyperandrogenism'. Journal of American Academy of Dermatology1984; vol. 10: pp. 223-226.

14. Darley CR, Kirby JD, Besser GM, Munro DD, Edwards CRW and Rees LH. 'Circulating testosterone, sex hormone binding globulin and prolactin in women with late onset or persistent acne vulgaris'. British journal of dermatology1982; vol. 106: pp. 517-522.

15.Vexiau P, Husson C, Chivot M, Brerault JL, Cathelineau G. 'Androgen Excess in Women with Acne Alone Compared with Women with Acne and/or Hirsutism'. Journal of investigative dermatology1990; vol. 94: pp. 279-283.

16.Ginsberg GS, Birnbaum MD and Rose LI. 'Androgen abnormalities in acne vulgaris', Acta Derm Venereol1981; vol. 61(5): pp. 431-434.

17.Fiet J, Gosling JP, Soliman H, Galons H, Boudou $\mathrm{P}$, Aubin $\mathrm{P}$, et al. 'Hirsutism and Acne in Women: Coordinated Radioimmuno assays for Eight Relevant Plasma Steroids'. Clinical Chemistry1994; vol.40 (12): pp. 2296-2305.

18.Ganong WF. 'The gonads: development and function of reproductive system'. Review of Medical Physiology. $20^{\text {th }}$ ed USA: Lange Medical Books/Mc Graw-Hill, Medical Publishing Division; pp. 398,431.

19. Henze Ch, Hinney B, Wuttke W. 'Incidence of Increased Androgen levels in patients suffering from Acne'. Dermatology1998; vol. 196: pp. 53-54.

20. Jakubovic HR and Ackerman AB. 'Structure and function of skin: Development, morphology and physiology'. Dermatology, $3^{\text {rd }}$ ed. Philadelphia, USA :W.B. Saunders company publisher; pp. 66-69.

21.Lawarence DM, Katz M, Robinson WE, Newman MC, McGarrigle HHG, Shaw $M$ and Lachelin GCL.'Reduced sex hormone binding globulin and derived free testosterone levels in women with severe acne'. Clinical Endocrinology1981; vol. 15: pp. 87-91.

22.Lim LS and James VHT . 'Plasma androgens in acne vulgaris'. British Journal of Dermatology2006; vol. 91: pp.135-143.

23.Lucky AW, Biro FM, HusterGA, Leach AD. Morrison JA, Ratter man J. 'Acne Vulgaris in Premenarchal Girls'. Arch Dermatol1994; vol.130: pp. 308-314.

24.Lucky AW, Mcguire J, Rosenfield RL, Lucky PA and Rich BH. 'Plasma Androgens in Women with Acne Vulgaris'. The Journal of investigative dermatology1983; vol. 81: pp. 70-74.

25. Nader S, Rigaue LJR, Smith KD, Steinberger E. 'Acne and hyperandrogenism: Impact of lowering androgen levels with glucocorticoid treatment'. Journal of the American Academy of Dermatology1984; vol.11: pp. 256-259.

26. Seirafi H, Farnaghi F, Farhani AV, Alirezaie NS, Esfahanian F, Firooz A and Ghodsi SZ. 'Assessment of androgens in women with adult-onset acne'. International journal of dermatology2007; vol. 46:pp. 1188-1191. 